\title{
Building natural science learning through youth science camps
}

\author{
Piia Nuora and Jouni Välisaari \\ Department of Chemistry, University of Jyväskylä, Finland
}

\begin{abstract}
This study focuses on a youth science camp for pupils in sixth to ninth grades that is organized annually by the University of Jyväskylä, Finland. The main idea of the science camp is to learn to do guided inquiry in nature. The study investigates the significance of science camp for encouraging young participants to learn science and how the camp supports their learning. The research method used was a survey. Altogether, 47 youth participated in the camp in 2012 and 2013. The results show that the participants wanted to learn more about science than secondary school could offer, and science camp had a positive impact on their interest in science. It was possible to introduce important concepts of chemistry and biology in a comprehensible manner through experimentation in an authentic context. The participants worked as researchers in a positive and non-formal learning environment and they received concrete experience with the various phases of scientific research.
\end{abstract}

Keywords: narrative research, non-formal learning, non-formal science education, science camp, scientific inquiry

Contact: pia.nuora@jyu.fi

DOI: https:/ / doi.org/ 10.31129/LUMAT.6.2.326

This article is based on the academic dissertation of the author Piia Nuora: Nuora, P. 2016. Monitapaustutkimus LUMA-toimintaan liittyvissä oppimisympäristöissä tapahtuvista kemian oppimiskokemuksista. Department of Chemistry, University of Jyväskylä Research Report No. 197. Jyväskylä: University of Jyväskylä.

\section{Introduction}

The development of scientific literacy is one of the main goals of science education in many countries (Khishfe, 2008; Leblebicioglu, Metin, Yardimci \& Berkyurek, 2011a). The key element in scientific literacy is to understand the nature of science (NOS), science practices and researchers' activities (Vesterinen, 2012). Science camps help to develop scientific literacy (Foster \& Shiel-Rolle, 2011) and inspire youth to study natural sciences by offering an alternative learning opportunity to formal learning in a freer environment. According to Robbins and Schoenfisch (2005), science camps can motivate youth to learn science by helping them to see that they have the potential and ability to become natural scientists. The students are highly motivated to learn in camp. Adding the component of being in nature and investigating phenomena may 
add authenticity to students' experience (Leblebicioglu et al., 2017). According to Kong, Dabney, and Tain (2014), science camps have been studied from two different perspectives: (1) the science camps themselves and what the participants have learned during the camp, and (2) the extent to which camps affect the future interest of participants in the natural sciences. In this study, science camps are studied as a form of non-formal science education. Attention is also paid to the scientific inquiry education.

\subsection{Non-formal science education}

The importance of informal learning has increased in the teaching of natural sciences. Fields (2009) argues that a little-studied form of informal learning in natural sciences are science camps where pupils spend a relatively short but intense period (e.g., Foster \& Shiel-Rolle, 2011). Science camps include informal learning, but they could be better suited to meet aspects of non-formal learning. Informal learning mainly means everyday learning which is not organized (Coll, Gilbert, Pilot \& Streller, 2013) and applies to situations in life that come about spontaneously (Eshach, 2007). Nonformal learning means voluntary learning that is organized (Leblebicioglu et al., 2017) and which takes place in a systematic but highly adaptable manner in situations beyond the spheres of formal or informal education. In science camp there is a program and a schedule of activities. However, the experience occurs outside of a formal school setting (Leblebicioglu et al., 2017). The motivation for learning may be fully intrinsic to the learner even though non-formal learning shares the characteristic of being mediated with formal education (Eshach, 2007).

\subsection{Scientific inquiry education}

Scientific inquiry (SI) is considered the centerpiece of science teaching (AntinkMeyer, Bartos, Lederman \& Lederman, 2014; Williams, Ma, Prejean, Ford \& Lai, 2007). Until about 60 years ago, the term inquiry had a prominent role in middleand secondary school science (Hassard \&Dias, 2009). In practice, the term inquiry is used to refer to (1) SI, (2) inquiry learning and (3) inquiry teaching (Anderson, 2007). SI is defined by Schwartz, Lederman and Lederman $(2008$, p. 3) as "the characteristics of the processes through which scientific knowledge is developed, including the conventions of development, acceptance, and utility of scientific knowledge" (see also Hassard \&Dias, 2009, p. 35; Schwartz, Lederman \&Crawford, 2004, p. 612). Hassard and Dias (2007) express that inquiry learning refers to the process of learning science 
by methods. Those methods emulate those of scientific reasoning and inquiry is something that students do, not something done to them. In other words, inquiry learning is something whereby students gain understanding of phenomena via scientific ways of knowing (Hassard \& Dias, 2007).

The knowledge and practice of SI include the following: (1) asking scientific questions, (2), informing those questions through methodologically relevant means, (3) analyzing data, and (4) utilizing, modifying, and creating scientific models (Antink-Meyer et al., 2014). Hofstein, Kipnis, and Abrahams (2013) highlight that asking relevant and scientifically oriented questions is an integral part of SI (e.g., Chin \& Osborne, 2008). Hofstein et al. (2013) add that the formulation of a good question is at the heart of what doing science is all about. For example, questions from students indicate that (1) they have been thinking about the ideas presented, and (2) they have been trying to link them with other things they know (Chin \& Osborne, 2008). At science camp, almost all of the aforementioned phases of SI take placein experimental work. By doing scientific research, it is also possible to develop an understanding in the students of the nature of the sciences.

\subsection{Science camps at the Konnevesi Research Station}

The Department of Chemistry at the University of J yväskylä, Finland, has organized science camps for teenagers since 2010 at the Konnevesi Research Station. The Konnevesi Research Station is part of the Department of Biosciences and Environmental Science at the University of Jyväskylä. Science camps are part of the science, technology, engineering and mathematics (STEM) activities organized by the Department of Chemistry. The number of participants in the science camps has ranged between 10-25. The organization of the science camps started with the idea of providing meaningful activities for those youth who are interested in the natural sciences. The aim of the science camp was to support youth scientists to better understand the nature of the natural sciences. Youth are offered an opportunity to develop scientific thinking in the form of versatile experimental work. The phases of the scientific research are emphasized. The ultimate idea was to provide youth with a camp in which they might build a learning community. An additional aim was to open experiments of natural sciences through study of the surrounding nature. The goal of the camps was to reach high level thinking skills of Bloom's taxonomy (Krathwohl, 2002). Permanent topics of science camp include nature, water and the environment, while other topics have varied annually. In recent years, topics have become 
increasingly integrated with chemistry and biology. The themes are closely related to the nature surroundings of the research station. Science camps have been made more versatile by sharing the teaching responsibility between the chemistry and biology students who are teaching.

\section{Research}

The study approach is a case study, as it was desirable to study the same phenomenon in an actual context as deeply as possible.

The research was guided by the following research questions:

1. What is the significance of science camp for encouragingyouth to learn science?

2. How does science camp support youth learning of the natural sciences?

Section 2.1 explains what a case study means. Section 2.2 explains the procedure of the research and section 2.3 introduces the target group. Quality of the research is presented in Section 2.4. The results of the research are presented in Chapter 3 as a single report on the meaning of the science camp. Finally, Chapter 4 provides a summary of the study accompanied by conclusions.

\subsection{A case study}

A case study is considered to be more of an approach than a data collection or analysis method (Eriksson \& Koistinen, 2005). It explains a single case, seeking to understand the phenomenon in its context (Kananen, 2013). In a case study, the connection between the phenomenon and the context is not quite clear. Such a method of research is chosen when it comes to understanding a real-life phenomenon, but such understanding demands important contextual aspects (Yin, 2009). The researcher has the ability to determine what the case means in his/ her own research field (Patton 2015). The case can deal with an individual, group, institution or community (Kananen, 2013; Patton, 2015).

According to Eriksson and Koistinen (2005), a case study is selected as a research approach if one or more of the following conditions are met:

- The question words 'what,' how,' and 'why' are the key points.

- The researcher has only a small chance of controlling events.

- There is little empirical research on the subject being studied. 
- The research topic is a real-life, contemporary phenomenon.

\subsection{Implementation of the research}

The first author of this report served as the primary researcher and took primary responsibility for data collection, analysis, and interpretation. The second author planned and taught the science camp and also took responsibility for implementation, research analysis and interpretation.

The qualitative data, collected in 2012 and 2013, consists of questionnaires ( $\mathrm{N}=$ 47 ) and interviews ( $N_{\text {interviews }}=10$, respondents 18 ). The interviews were conducted as individual and group interviews. Analysis of narratives and narrative analysis were used. Narrativity is divided into two categories of material handling: narrative analysis and analysis of narratives. According to Patton (2015), narrative analysis focuses on how stories, especially texts that tell stories, are interpreted. Narrative analysis produces a new report on the basis of collected reports, which highlights the themes of the data. In analysis of narratives, the focus is on the categorization of reports (e.g., by case types, metaphors or categories; Heikkinen, 2010). Narratives and stories reflect the experiences of individuals, social structures and how the world is understood (Patton, 2015). Stories can be constructed as a typical event or a typical story can be presented as a whole from them (Eskola \& Suoranta, 2008). Narrative research uses a linear, analytical case study reporting methodology (see Eriksson \& Koistinen, 2005; Yin 2002), which outlines the starting points, material and methods of research, results and conclusions. In this study, the analysis included direct quotes from open responses and interviews in order to provide additional explanations for the answers. The narrative approach was chosen for the analysis phase because the focus was on adolescents' authentic stories (Heikkinen, 2010).

The participants received a cover letter and a study permission form by post before the camp, and they returned the permission form signed by a parent before attending the science camp. Instructions for completing the questionnaire were provided orally on the spot by the researcher. The questionnaire was answered anonymously. The problem with using questionnaires is that there is no chance to ask further questions. For this reason, an interview was used in 2012 in addition to the questionnaire. The amount of questionnaire data was small, but saturation was seen in the second year.

The research material was compiled so that the questionnaires were distributed to the campers at the beginning and end of the camp and they returned them to the 
researcher anonymously. It took about 15 minutes to complete the questionnaire, which contained open and closed questions. Due to the narrative approach, only open questions were taken into account in this research analysis.

An interview study was also conducted in 2012. At first, interviews were implemented as groups. Due to the effect of other groups members in the interview situation, the rest of the interviews were done individually. In this case, the interview can be classified as a thematic interview. The interview form was used because researchers sought additional insight on the questionnaire replies. The results of the interviews confirmed the results from the questionnaire. However, the interviews did not take place the following year, because it was observed that the answers failed to provide substantial additional value compared to the questionnaire. Two researchers independently analyzed the research data, and after the discussions, researchers came to a similar conclusion regarding which topics emerged the most from the answers.

\subsection{The target group}

In 2012, 25youths participated in the camp, and one did not participate in the survey. In 2013, 25 youths participated in the camp; two did not participate in the study. The average response rate was $94 \%$. The questionnaire consisted of three sections. In the first section, the respondent's background information was asked. The second part contained statements about science camp. The third part contained open questions related to the experiences gained from the science camp.

Respondents $(\mathrm{N}=47)$ were aged 12 to 16 years. Most of the campers were 14 years old (40\%, 19/47). While 59\% of respondents (27/46) were girls and 41\% (19/46) were boys, one did not answer the question about gender.

Attending the camp were youth from primary school, upper secondary school and vocational education institutions. Most of the participants were seventh- or eighthgraders (see Figure 1). 


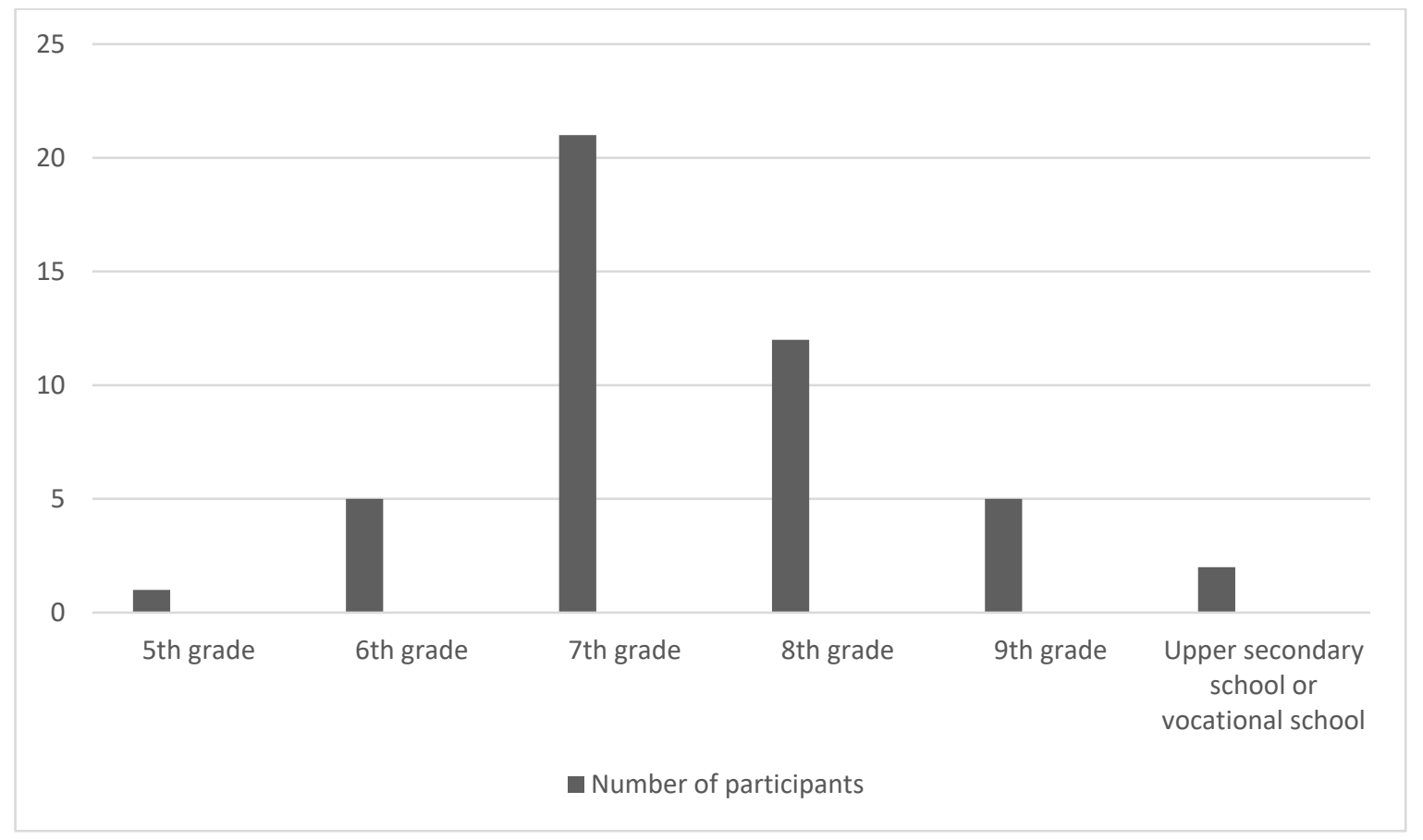

Figure 2. Campers' grade when they completed the school year.

\subsection{Quality of the research}

The advantage of interviews is that the interviewee has the opportunity to raise issues about his own perspective as extensively as desired. However, an interview contains many potential sources of error, which arise from both the interviewer and the interviewee. Reliability may be weakened by the interviewee's tendency to provide socially desirable answers (Hirsjärvi \&Hurme, 2011). Interviews included one person or groups of two or three people. In this study, group interviews posed a special challenge. It was evident that respondents responded to each other's responses. Respondents mingled with each other's answers. As a result, the rest of the interviews were conducted as individual interviews and only those responses were taken into account in the direct quotations of the analysis of the material. The identification details were properly discarded after the study was completed.

According to Heikkinen (2010), the reliability of narrative research can be viewed in light of the traditional concepts of trust in concepts of modernity: validity and reliability. Generally, validity means how the research results correspond to the actual state of facts and reliability means the extent to which random factors potentially affected the results of the research (Tuomi \& Sarajärvi, 2013). Efforts have been made to increase the credibility of the research. Describing the reports of the campers has aimed at fairness. This has been done by trying to treat the campers and their stories 
equally. In addition, all stages of the research process have been introduced as accurately as possible to give the reader a clear idea of their content. For narrative research, it is essential that the story opens to the reader. This has been done by adding enough direct quotations from the research material in the produced report. The research was carried out according to the guiding principles of scientific research, so the question of dependence on research was realized. The research data was small, but rich: data provided an in-depth look at the research questions. In a narrative case study, it is not relevant how many pages texts contain but their number of narratives (Partanen, 2011). Efforts were made to increase the validity of the research by highlighting critical aspects in the data. Also, the use of multiple coders in analysis phase and different type of research material may be seen as a form of triangulation. Triangulation, in this study the use of both interviews and questionnaire as a research method, adds credibility and validity to a research. (Tuomi \& Sarajärvi, 2013.) The independent analyses of two researchers and common conclusions reached after discussions also add to the reliability of the analysis. In a consensus-based theory of truth, people can create a "truth" by arriving at a consensus (Patton, 2015; Tuomi \& Sarajärvi, 2013).

\section{Results}

In the study, the data from questionnaire and interviews is presented using combined types. The story is built on the basis of both questionnaires and interviews. At the beginning of the data analysis, data was classified into types and different story types were examined. Attempts were made to look for temporal organization. The analysis was further extended and the answers were constructed to represent one typical tale in its entirety. (Eskola \& Suoranta, 2008.) Eskola and Suoranta (2008) distinguish three different ways of forming types. An authentic type contains one example of wider material describing the typical story of the material. The combined type is the most general and contains the things that occur in either a large percentage or all of the responses. The widest possible type includes content of the data presented in a variety of ways. This means that some of the things involved may have occurred in only one answer. The essence of such a type is its internal logic: the type is possible, although it is unlikely as such.

The study conformed to the widest possible type in order to highlight the unique features of the stories. This study will help to further develop the science camp in the 
future, and it will also serve to protect the identity of the investigators. The report can be described as a kind of summary in which certain elements of the responses were collected and arranged. Some of the issues were mentioned in only one answer, others in quite a few. (Eskola \& Suoranta, 2008.) Themes and stories construct the story and thus act as a turning circle of the plot.

Iisa, Oona and Paavo appear in the report and they are pseudonyms. Iisa and Oona are 14-year-old girls who were at the camp for the first time. Paavo is a 15-year-old boy who participated in the camp two times. Iisa, Oona and Paavo tell the story of why they wanted to go to the camp, what they expected from it, what was done at the camp and how the camp could be improved in the future. The themes reveal the main findings of the story. A report was built on the data, which proceeds chronologically from the beginning of the science camp to the present.

\section{The story about participating in the science camp}

\subsection{Before the science camp}

From Iisa, Oona and Paavo's responses it was apparent that the most important issues in science camp were related to learning content and cooperation. Youth felt they learned new things in both biology and chemistry. Iisa mentioned, for example, the calculation of water oxygen content, the identification of cloud forms and the use of a microscope. Paavo, in turn, told that he was motivated by the study of lake water, insect and stone studies, and the production of a layered drink. Youth also felt that there was a good time to rehearse of what had been learned earlier in school.

.. I want to be a chemist as an adult. (Oona)

\subsection{Youth learned at the science camp...}

Iisa, Oona and Paavo wanted to join the science camp because they were interested in natural sciences and because the topics that were in the program during the participation year were interesting. As examples from those topics, Iisa and Paavo mentioned crime scene investigation and the Amazing Race competition.

The fact that I learn different things about science, like various measurements, and so on... (Oona) 
The camp supported group work. Cooperation has many good aspects: it helps in grouping, and peer support during experimentation is of paramount importance for many youths. Oona highlighted the importance of grouping in relation to other people's lives. Oona said that the most important thing in the camp for her own life was that she learned to interact with complete strangers.

The most important thing for my life was that I learned to interact with complete strangers. It has been difficult for me earlier. (Oona)

\subsection{Thoughts about the successes and weaknesses of the science camp}

Iisa, Oona and Paavo considered the good aspects of the science camp from many different perspectives. The campers gave positive feedback regarding various factors related to camp life. The answers showed the importance of being together. The camp brought together similar kinds of thinking youth with a shared interest in natural sciences. The science camp was considered to be a more diverse camp than other camps usually are because science is learned and actually done.

I got new friends and learned all about new things in chemistry and biology. (Oona)

I think this is a really good group, with everybody being a bit with everyone. (Paavo)

Paavo pointed out tolerance and that it was nice to do research together with other campers. Campers did experiments in different groups, varying their workload. This helped them to get to know other campers better. New friends and nice teachers were an inspirational factor in creating team spirit.

Experimental work in the science camp differs from work done in secondary school by taking advantage of the nature environment at the research station as much as possible. The genuine nature environment provides many new opportunities for teaching that traditional classrooms cannot offer. At the camp, a lot of new experiments were performed in the field of nature. Paavo told that the assignments were interesting, and he felt it was important that they were adequate. However, it is good to remember that mere experimentation is not sufficient to understand natural phenomena. Students should also correctly understand the content of the work. (Clough, 2002.) 
It is always fun to do hands-on experimentation. Most of the campers were really enthusiastic about the topics and so were the teachers. There was a DNA story told late in the evening at the request of campers. (Iisa)

...biology and the Amazing Race may be the nicest program, and leisure was really nice, with sauna + swimming. (Oona)

...got to go to the lab to investigate insects. (Oona)

Iisa, Oona and Paavo's thoughts regarding the negative aspects of the camp were mainly related to practical arrangements. Iisa and Paavo reported that many campers thought that there was nothing wrong with the camp. Some youth criticized the contents of the curriculum. For example, Oona felt that the material was not adequately covered after the study.

The only minus was the nature trail. Rushing in the woods and the long walk were not very nice to do. (Paavo)

Iisa mentioned that she was annoyed because there were less chemistry studies than expected. In 2013, biology was more integrated into the teaching. Oona, on the other hand, felt a little uncertainty about her own subject knowledge. Paavo felt that the experiments were too easy. The campers' age range was originally from the seventh to ninth grade, but sixth-grade youth participated in the camp if there was still room for them.

That you did not at times know all the things...(Oona)

Part of the program works seemed to be oriented to younger people than the camp's age limit was. (Paavo)

Campers would have liked to choose the groups themselves and they thought that the groups should have been smaller. Youth felt that self-selected groups may have worked better than those selected for them. Teachers assembled groups that were varied, so that campers could learn more about each other. Iisa, Oona and Paavo felt that in some situations the group was too big for older students to get to know the other campers.

Groups could have chosen themselves so they might have worked better. (Paavo) 


\subsection{The science camp had an impact on interest in biology and chemistry}

The aim of the science camp was to increase interest in natural sciences. Iisa and Oona's answers reflected the importance of the camp to enhance enthusiasm and interest. The youth who came to the camp were already interested in science. The science camp offered an opportunity to explore new things and it enhanced motivation.

I am interested in biology and chemistry more because I like to learn new things and this science camp has helped me to learn new things. (Oona)

According to Paavo, the camp had no effect on increasing interest in natural sciences. Paavo justified this by saying that he could not be more interested than presently. In science camp was possibility to apply the knowledge in new learning contexts.

It opened different perspectives on things and that affected positively. (Iisa)

\subsection{Youth gave development ideas for the future}

Iisa, Oona and Paavo hoped for more chemistry and biology content-related things in the camp. Youth hoped for chemistry-related laboratory work. Also, there was a perceived need for more theory and deeper knowledge of different things. Youth may be seen as experiencing things superficially. In addition, they thought that the difficulty of the subjects being discussed could be increased, because the camp is targeted at secondary school students.

More theory, deeper knowledge about different things...(Oona)

Oona thought that the camp could also introduce other natural sciences. Integration of physics, mathematics and geography could be possible in the future. Youth would have wanted more work with their own group. Also, they wanted more experiments in nature. As the eldest in his group, Paavo noted that in the future it would be nice if there could be a camp for people of different ages, such as high school students.

I would have wanted freedom of choice and variety in the groups! (Paavo)

More days! (Iisa) 


\section{Summary and conclusions}

The study explored how youth can be encouraged to learn science through a science camp. The study also examined how youth experience science camp as supporting their learning of the natural sciences. When youth came to the camp, they were interested in natural sciences and wanted to learn new things about chemistry and biology. However, the science camp managed to increase enthusiasm and interest in natural sciences (see also Bhattacharyya, Mead \& Nathaniel, 2011). Participants had a chance to learn science in new contexts and there were new friends and teachers encouraging them to learn science. Lindner and Kubat (2014) have also found the same kind of conclusions: science camp participants in Germany and Denmark both show the same tendencies. A five-day camp increases the interest in science. The majority of participants $(70 \%, \mathrm{~N}=52)$ report an increase of interest in science and technology (Lindner \& Kubat, 2014). Science camps can be said to be the type of extracurricular learning environment that develops positive feelings towards the natural sciences.

Youth are more motivated to study natural sciences if they are offered newlearning experiences in an authentic context. This has a positive impact on learning outcomes (Hofstein \&Lunetta, 2004; Watson, Swain \& Robbie, 2004). In science camp there is a small amount of teacher-led instruction, which helps students to understand new concepts and things. Most of the experimental work involves hands-on experiments. The campers felt that the science camp positively influenced their interest in natural sciences: the topics were interesting and there was enough experimentation that was connected to the real world.

Most of the campers perceived that experimentation was the most sensible way of studying chemistry. Interesting experimental work deepened youth's knowledge of chemistry and biology. Experimentation can be seen as an important aspect of learning natural sciences because it provides personal experience (see Bradley, Durbach, Bell \& Mungarulire, 1998). This was seen in, for example, Iisa's comment after our science camp: "It is always fun to do hands-on experimentation. Most of the campers were really enthusiastic about topics..." Phenomena were examined in authentic contexts and thus youth were introduced into phenomenal learning. Although experimentation played a central role in the camp, it was even more desirable to have learning contents related to the camp and laboratory work. The camp served as a good reinforcement of what had been learned earlier in school, and 
through using experimentation, group work and discussions it helped to develop critical thinking skills.

The study shows that science camp can lead to a better understanding of the nature of information obtained from SI. The science camp utilizes various types of learning styles to encourage youth to conduct scientific research. This helps different kinds of learners to find their own best way of learning science. Science camps organized by the University of Jyväskylä have played a major role in bringing experimental, research-oriented science and science-oriented youth closer together. It was possible to introduce important concepts of science in an understandable manner through experimentation in a natural environment. The camp imitates an authentic research situation in a non-formal learning environment where youth work as researchers. Extracurricular contexts can stimulate pupils to think more deeply about science and providenewconnections to science (Braund \&Reiss, 2006). According to the research literature, the camps help to develop scientific thinking (Leblebicioglu, Metin, Yardimci \& Cetin, 2011b) and campers are excited to ask more questions (Sterling, Matkins, Frazier \& Logerwell, 2007).

Campers came to the science camp from all over Finland, and many campers were alone in a new situation. Shared leisure time allowed the campers to get to know each other better. Working in a group was considered an important issue: youth were placed in teams to solve common problems and tasks. Regarding cooperation, it is important that campers support each other in doing the tasks and that the research conclusions are made together (see Auno et al., 2016). It became clear in this study that youth dared to ask questions of concern and questions were considered together by other youth and instructors. Asking relevant and scientifically oriented question is an integral part of SI (Hofstein et al., 2013). Cooperation with other campers and instructors supports a positive socialization experience (Fields, 2009; Kong et al., 2014). The camp was felt to be a functional and positive extracurricular learning environment in which youth shared the same interests.

Eventually, the camp might be developed to target elementary or older students. During the years studied here, the campers were mostly in sixth to ninth grade. That difference in age is too wide for activities to be suitable for all campers. The chemistry knowledge of sixth graders is not very advanced yet, and in turn, maintaining ninth graders' interest is challenging if a lot of the work is too easy for them. Martinez and Hibbs (2003) studied summer camps and they came to the conclusion that seventh to twelfth grade is too large of an age gap to keep the twelfth graders interested without 
losing the seventh graders. In this research, the interest of older students in the camp involved the responsibility of takingyounger campers into consideration. Camps have emphasized an openness to experimentation and providing space and time for campers' questions and personal interests. These will advance campers' knowledge of the natural sciences.

The youth science camp supports the learning of chemistry and attracting interest in STEM subjects by providing youth with new learning experiences in a genuine context. Youth's answers highlighted the positive feedback. It can be concluded from this that the science camp is a functional entity. The results here can be utilized in the development of this and other science camps. In addition, researchers hope that this could encourage other teachers and universities to organize science camps for youth. During science camp, it is worthwhile to reserve enough time to work in groups and to make inquiries. There should also be teacher-led instruction in science camp settings and time for questions and discussion by young people. Science camp works when there are motivated, science-oriented young people and an interesting learning environment.

\section{References}

Anderson, R. D. (2007). Inquiry as an organizing theme for science curricula. In S. K. Abell \& N. G. Lederman (Eds.), The Handbook of Research on Science Education (pp. 807- 830). Mahwah, NJ : Lawrence Erlbaum Associates.

Antink-Meyer, A., Bartos, S., Lederman, J . S., \&Lederman, N. G. (2014). Using science camps to develop understanding about scientific inquiry - Taiwanese students in a U.S. summer science camp. International J ournal of Science and Mathematics Education, 14(1), 29-53.

Auno, P., Heikkinen, E., Itkonen, H., Karhu, A., Karjalainen, R.-L., Korkealehto, K., ... Takala, K. (2016). Pedagoginen toimintamalli 2016 - Älyllä ja ilolla osaajaksi. Kajaanin ammattikorkeakoulun julkaisusarja B, raportteja ja selvityksiä 54 .

Bradley, J . D., Durbach, S., Bell, B., \& Mungarulire, J . (1998). Hands-on practical chemistry for all - Why and how? J ournal of Chemical Education, 75(11), 1406- 1409.

https:/ / doi.org/ 10.1021/ ed075p1406

Braund, M., \& Reiss, M. (2006). Validity and worth in the science curriculum: Learning school science outside the laboratory. The Curriculum J ournal, 17(3), 213- 228. https:/ / doi.org/ 10.1080/ 09585170600909662

Chin, C., \&Osborne, J . (2008). Students' questions: A potential resource for teaching and learning science. Studies in Science Education, 44, 1- 39.

Clough, M. P. (2002). Using the laboratory to enhance student learning. In R.W. Bybee (Eds.) Learning science and the science of learning. National Science Teachers Association, (pp. 85-94).

Coll, R. K., Gilbert, J . K., Pilot, A., \& Streller, S. (2013). How to benefit from the informal and interdisciplinary dimension of chemistry in teaching. In I. Eilks \&A. Hofstein (Eds.) 
Teaching Chemistry - A Studybook. A practical guide and textbook for student teachers, teacher Trainees and teachers (pp. 241- 268). Rotterdam: SensePublishers.

Eriksson, P., \&Koistinen, K. (2005). Monenlainen tapaustutkimus. Kuluttajantutkimukeskus, Julkaisuja 4.

Eshach, H. (2007). Bringing in-school and out-of-school learning: Formal, non-formal and informal education. J ournal of Science Education and Technology, 16(2), pp. 171-190.

Eskola, J ., \& Suoranta, J . (2008). J ohdatus laadulliseen tutkimukseen. Tampere: Vastapaino.

Fields, D. A. (2009). Research Report: What do students gain from a week at science camp? Youth perceptions and the design of an immersive, research-oriented astronomy camp. International J ournal of Science Education, 31(2), 151- 171.

Foster, J . S., \& Shiel-Rolle, N. (2011). Building scientific literacy through summer science camps: A strategy for design, implementation and assessment. Science Education International, 22(2), 85- 98.

Hassard, J ., \&Dias, M. (2009). The art of teaching science - Inquiry and innovation in middle school and high school (2nd ed.). New York: Routledge.

Heikkinen, H. L. T. (2010). Narratiivinen tutkimus - todellisuus kertomuksena. In J . Aaltola \& R. Valli (Eds.) Ikkunoita tutkimusmetodeihin II. Näkökulmia aloittavalle tutkijalle tutkimuksen teoreettisiin lähtökohtiin ja analyysimenetelmiin, (pp. 143- 159). J uva: PSkustannus.

Hirsjärvi, S., \& Hurme, H. (2011). Tutkimushaastattelu - Teemahaastattelun teoria ja käytäntö. Helsinki: Gaudeamus.

Hofstein, A., Kipnis, H., \& Abrahams, I. (2013). How to learn in and from the chemistry laboratory. In I. Eilks \&A. Hofstein (Eds.): Teaching Chemistry - A Studybook: A Practical Guide and Textbook for Student Teachers, Teacher Trainees and Teachers, (pp. 153- 182). Rotterdam: SensePublishers.

Hofstein, A., \&Lunetta, V. N. (2004). The laboratory in science education: Foundations for the twenty-first century. Science Education, 88(1), 28- 54. https:/ / doi.org/ 10.1002/ sce.10106

Kananen, J . (2013). Case-tutkimus opinnäytetyönä. J yväskylän ammattikorkeakoulun julkaisuja 143.

Khishfe, R. (2008). The development of seventh grader's views of nature of science. J ournal of Research in Science Teaching, 45(4), 470- 496. https:/ / doi.org/ 10.1002/ tea.20230

Kong, X., Dabney, K. P., \& Tai, R. H. (2014). The association between science summer camps and career interest in science and engineering. International J ournal of Science Education, Part B, 4(1), 54-65. https:/ / doi.org/ 10.1080/ 21548455.2012.760856

Krathwohl, D. R. (2002). A revision of Bloom's taxonomy: An overview. Theory into Practice, 41(4), 212-218. Retrieved from http:/ / jstor.org/ stable/ 1477405

Leblebicioglu, G, Metin, D., Yardimci, E., \&Berkyurek, I. (2011a). Teaching the nature of science in the nature: A summer science camp. Elementary Education Online, 10(3), 1037- 1055.

Leblebicioglu, G, Metin, D., Yardimci, E., \& Cetin, P. S. (2011b). The effect of informal and formal interaction between scientists and children at a science camp on their images of scientists. Science Education International, 22, 158- 174.

Leblebicioglu, G., Abik, N. M., Capkinoglu, E., Metin, D., Eroglu Dogan, E., Cetin, P. S., \& Schwartzh, R. (2017). Science camps for introducing nature of scientific inquiry through student inquiries in nature: Two applications with retention study. Research in Science Education, 1-25. https:/ / doi.org/ 10.1007/ s11165-017-9652-0

Lindner, M., \&Kubat, C. (2014). Science camps in Europe - Collaboration with companies and school, implications and results on scientific literacy. Science Education International, 25(1), 79- 85. 
Martinez, D., \& Hibbs, M. (2003). Using summer camps to motivate rural students in science and engineering. In ASEE/IEEE Frontiers in Education Conference. Boulder, CO, pp. F2D-7. https:/ / doi.org/ 10.1109/ FIE.2003.1264704

Nuora, P. (2016). Monitapaustutkimus LUMA-toimintaan liittyvissä oppimisympäristöissä tapahtuvista kemian oppimiskokemuksista. Research report No. 197, Department of Chemistry. University of Jyväskylä.

Partanen, A. (2011). "KYLLÄ MINÄ TÄSTÄ SELVIÄN” - Aikuisopiskelijat koulutustarinansa kertojina ja koulutuksellisen minäpystyvyytensä rakentajina. Jyväskylä: Jyväskylän yliopisto, Kokkolan yliopistokeskus Chydenius.

Patton, M. Q. (2015). Qualitative research \& evaluation methods (4th ed.). SAGE Publications.

Robbins, M. E., \& Schoenfisch, M. H. (2005). An interactive analytical chemistry summer camp for middle school girls. J ournal of Chemical Education, 82(10), 1486- 1488.

Schwartz, R. S., Lederman, N. G., \& Crawford, B. A. (2004). Developing views of nature of science in an authentic context: An explicit approach to bridging the gap between nature of science and scientific inquiry. Science Teacher Education, 88(4), 610- 645. https:/ / doi.org/ 10.1002/ sce.10128

Schwartz, R. S., Lederman, N. G., \&Lederman, J . S. (2008). An instrument to assess views of scientific inquiry: the VOSI questionnaire. National Association for Research in Science Teaching, Baltimore, U.S.

Sterling, D. R., Matkins, J .J ., Frazier, W. M., \&Logerwell, M. G. (2007). Science camp as a transformative experience for students, parents, and teachers in the urban setting. School Science and Mathematics, 107(4), 134- 148. https:// doi.org/ 10.1111/j.19498594.2007.tb17928.x

Tuomi, J ., \& Sarajärvi, A. (2013). Laadullinen tutkimus ja sisällönanalyysi. Helsinki: Tammi.

Vesterinen, V.-M. (2012). Nature of science for chemistry education. Design of chemistry teacher education course. Department of Chemistry. University of Helsinki.

Watson, J . R., Swain, J . R. L., \&McRobbie, C. (2004). Students' discussions in practical scientific inquiries. International J ournal of Science Education, 26(1), 25- 45. https:/ / doi.org/ 10.1080/0950069032000072764

Williams, D. C., Ma, Y., Prejean, L., Fold, M. J ., \& Lai. G. (2007). Acquisition of physics content knowledge and scientific inquiry skills in a robotics summer camp. J ournal of Research on Tehnology in Education, 40(2), 201-216. https:/ / doi.org/ 10.1080/ 15391523.2007.10782505

Yin, R. K. (2009). Case study research - Design and methods (4th ed.). Applied Social Research Methods Series, Vol 5. Sage. 